\title{
Influence of Storage on Darkening and Hardening of Slow- and Regular-Darkening Carioca Bean (Phaseolus vulgaris L.) Genotypes
}

\author{
Beatriz S. Siqueira \\ Faculty of Agronomy and Food Engineering, Federal University of Goiás \\ Campus Samambaia - Rodovia GO-462, Km 0, 74690-900 Goiânia, GO, Brazil \\ Tel: 55-62-3514-9500Ｅ-mail: beatrizsiqueira7@gmail.com
}

Wendell J. Pereira

Biological Science Institute, Federal University of Goiás

Caixa Postal 131 - CEP 74001-970-Goiânia, Goiás, Brazil

Tel: 55-62-8224-4961Ｅ-mail: wendell.j.p@hotmail.com

Karla A. Batista

Biological Science Institute, Federal University of Goiás

Caixa Postal 131 - CEP 74001-970-Goiânia, Goiás, Brazil

Tel: 55-62-521-1492Ｅ-mail: karla-batista@ hotmail.com

B. Dave Oomah

(Retired), Formerly with National Bioproducts and Bioprocesses Program, Pacific Agri-Food Research Centre, Agriculture and Agri-Food Canada, 4200 Highway 97, P.O. Box 5000, Summerland, BC, Canada V0H $1 \mathrm{Z0}$

Tel: 1-250-770-1454 E-mail: oomahd@gmail.com

Kátia F. Fernandes

Biological Science Institute, Federal University of Goiás

Caixa Postal 131 - CEP 74001-970-Goiânia, Goiás, Brazil

Tel: 55-62-521-1492 E-mail: kfernandes.lqp@gmail.com 
Priscila Zaczuk Bassinello (Corresponding author)

Food Science Researcher, Embrapa Rice and Beans

Rodovia GO-462, km 12 Zona Rural C. P. 179, 75375-000

Santo Antônio de Goiás, Goiás, Brazil.

Tel: 55-62-3533-2186 E-mail: priscila.bassinello@embrapa.br

Received: June 24, 2014 Accepted: July 15, 2014

doi:10.5296/jas.v2i2.5859

URL: http://dx.doi.org/10.5296/jas.v2i2.5859

\begin{abstract}
New carioca bean cultivars are being introduced into the market necessitating their evaluation under trade conditions, which often require storage under ambient conditions. We therefore evaluated the darkening and hardening processes of six carioca bean genotypes each representing regular and slow darkening trait during storage under ambient conditions for five months to elucidate their relationship as a breeding strategy. Storage time adversely affected color characteristics $\left(\mathrm{L}^{*}, \mathrm{a}^{*}, \mathrm{~b}^{*}, \mathrm{C}^{*}\right.$ and $\left.\Delta \mathrm{E}\right)$ depending on bean genotype, whereas hardness and resistance to cooking increased during storage independent of the lignification process. Bean darkening and hardening occurred during storage at different intensities in each genotype and were not always correlated. BRSMG-Madrepérola, a slow darkening genotype, was unaffected (resistant to storage conditions), whereas BRS-Pontal with regular tegument darkening, was highly susceptible to storage conditions reflected in extended cooking time and darkening (low $\mathrm{L}^{*}$ values). Principal component and cluster analyses on 8 constituents analyzed in this study demonstrate the difference in color characteristics, cooking time and hardness as major factors in segregating the bean genotypes. Seed coat color is an important but inappropriate single parameter for predicting the resistance to cooking or hardness induced by storage of carioca beans under ambient conditions. Development of carioca bean genotypes resistant to storage conditions is essential in reducing food losses during postharvest.
\end{abstract}

Keywords: Ambient conditions, Chromaticity, Cooking time, Darkening, hardness, Lignification, Luminosity, Carioca, Phaseolus vulgaris.

\title{
1. Introduction
}

Seed coat postharvest darkening occurs in some market classes of dry bean, particularly pintos, reds and cariocas (cream background with tan stripes). It causes considerable economic loss because of an undesirable decline in visual quality that consumers associate with prolonged cooking time. Seed coat darkening and increased cooking time are associated with the "hard-to-cook" (HTC) phenomenon found in some legume species, particularly dry bean. The exact causes of postharvest darkening are not well-known, but include a combination of environment, genetics, and chemical changes that take place within the seed coat (Beninger et 
al., 2005). Darkening is accelerated by exposure to light, high temperature, and humidity prevalent during postharvest carioca bean storage in Brazil. Therefore, the study of darkening resistant genotypes might be useful to identify distinctive or common mechanism needed for quality maintenance under local storage conditions.

Common beans (Phaseolus vulgaris L.) vary extensively in characteristics and consumer preferences are primarily based on physical attributes; color, shape and size of the grain. Seed coat color is the most important attribute in marketing carioca bean type, because consumers prefer light color grains. Beans with darker seed coat color have low acceptance, as consumers associate them with grains resistant to cook (HTC) and poor sensory quality (Nasar-Abbas et al., 2008a).

Previous studies have focused on the effects of storage conditions on bean darkening and/or reduction in cooking time. Genetic studies of early grain darkening showed that storage time accentuates the difference between quick darkening and darkening-resistant carioca bean genotypes (Silva, Ramalho, Abreu, \& Silva, 2008). Furthermore, the heritability of grain darkening increases with storage time and genetic control appear to be monogenic with dominance for the allele for early darkening (Silva et al., 2008). Carioca bean darkening was highly associated with cooking time depending on phenotypic $(\mathrm{r}=0.694, \mathrm{P}<0.05)$ and genetic $(r=0.868)$ traits when assessed 60 days after harvest (Araújo, Ramalho, \& Abreu, 2012).

Cultivar differences were observed in cooking time of carioca beans stored under refrigeration $\left(0{ }^{\circ} \mathrm{C}, 50 \%\right.$ relative humidity) at 0,3 and 6 months; cooking time was also dependent on the interaction of cultivar and storage time (Oliveira, 2009). Prolonged cooking time of beans (recombinant inbred sulfur-yellow lines) decreased progressively over time during storage at room temperature and $5{ }^{\circ} \mathrm{C}$ for 35,42 and 53 days relative to freshly harvested beans. This hardening apparently caused by frost, was partially reversed by 62 days of storage, either chilled or at room temperature (Jacinto-Hernández, Garza-García, Garza-García, Bernal-Lugo, 2013). Hardness of carioca bean increased 55 and $128 \%$ under control $\left(5^{\circ} \mathrm{C}\right)$ and accelerated aging $\left(40{ }^{\circ} \mathrm{C}, 76 \% \mathrm{RH}\right)$, respectively for 2 months storage relative to freshly harvested grains (Coelho, Prudêncio, Christ, Sampaio, \& Schoeninger, 2013). Cooking time of 17 carioca bean genotypes grown in eleven environments and stored at room temperature from 30 to 90 days varied significantly $(\mathrm{P}<0.01)$ among genotypes, environments and their interaction. Furthermore, environment (cropping season, location and storage period) contributed more to the variability in cooking time than genotypes (Torga et al., 2011).

In Brazil, beans are stored mostly under high temperature, humidity and light conditions, rendering the beans susceptible to the development of the hardening and darkening phenomena (Coelho, Prudêncio, Nóbrega, \& Leite, 2009). It is thought that complex reactions are activated inside the grains, involving different cell components such as cell wall polymers, phenolics, starch, protein and enzymes, initiating the hardening and/or darkening phenomena (Berrios, Swanson, \& Cheongh, 1998; Garcia, Filisetti, Udaeta, \& Lajolo, 1998). The degree and speed at which grains develop these phenomena may also be associated with the environment (climate and soil) in which beans were grown, as well as their intrinsic characteristics (Ribeiro et al., 2007). 
Beans susceptibility to hardening during storage directly affects their marketing, trade and consumption. Although beans are rich in nutrients that make their consumption advantageous (Cardador-Martínez, Loarca-Piña, Oomah, 2002; Oomah, Corbe, \& Balasubramanian, 2010) they are often overlooked by less nutritious, fast-cooking or precooked foods. This change in dietary habits of the population calls for serious strategy to reduce the cooking time and/or introduce fast cooking bean types (Leterme \& Muñoz, 2009).

In bean marketing, the association of seed coat color with the hardness process is so recurrent that color parameter is a prime quality marker. Thus, the bean breeding programs aim to develop new cultivars that meet consumer demands, so that its high nutritional value is not replaced by poor nutritional foods. So, the priorities of breeding programs are to develop high yielding cultivars that are resistant to pests and diseases with short/fast cooking time (Lemos, Oliveira, Palomino, \& Silva, 2004), light color and lower susceptibility to darkening to increase the probability of acceptance by producers and consumers.

The carioca bean is the most cultivated and consumed in Brazil. However, storage conditions can adversely affect bean quality resulting in significant grain loss at the postharvest stages of the value chain, particularly in the middle and low-income countries. Carioca bean genotypes used in this study and often in other investigations have variable cooking time. Furthermore, variation in bean darkening was cultivar dependent during storage (13\% moisture, ambient conditions, 0, 90, and 180 days) (Siqueira, Teixeira, \& Bassinello, 2012).

This investigation extends our previous study focusing on elucidating the hardening and darkening process during prolonged (5 months) storage of contrasting carioca bean genotypes as well as their relationship that can be used as a component of carioca bean breeding strategy. Reducing quality losses under prolonged local storage conditions can better maintain the nutritional value of carioca beans, prevent postharvest loss and improve food security.

\section{Materials and Methods}

Seeds of carioca bean (Phaseolus vulgaris L.) genotypes (BRS-Estilo, BRSMG-Madrepérola, BRS-Pontal, BRS-Requinte, Pérola and CNFC10467) were obtained from the Bean Breeding Program of Embrapa Rice and Beans, Santo Antônio de Goiás, Brazil. The irrigated bean harvest took place from April to June 2011 at the Capivara Farm of Embrapa, located in the Middle West region of the country. All the recommended cultivation management was properly followed. The name of the genotypes is used hereafter without the prefix. CNFC10467, Madrepérola, and Requinte are considered elite genotypes with slow darkening trait, whereas Estilo, Pérola and Pontal are cultivars/elite lines with regular tegument darkening (Silva et al., 2011).

\subsection{Storage Treatment}

Prior to storage, harvested beans were dried naturally to a final moisture content of approximately $12 \%$. Beans were divided into three lots of approximately $2 \mathrm{~kg}$ each and packed in transparent polyethylene bags and stored for five months under uncontrolled conditions in a room with natural light from the rising sun. The samples were placed randomly and rotated regularly in the storage tray. Temperature and relative humidity were monitored during the 
storage period (Table 1).

Table 1. Temperature and relative humidity during carioca bean storage* .

\begin{tabular}{|c|c|c|}
\hline Storage month & Temperature $\left({ }^{\circ} \mathrm{C}\right)$ & Relative Humidity $(\%)$ \\
\hline July & $25.06 \pm 1.28$ & $53.48 \pm 6.21$ \\
\hline August & $23.83 \pm 2.20$ & $35.33 \pm 9.52$ \\
\hline September & $25.05 \pm 1.44$ & $33.96 \pm 12.00$ \\
\hline October & $22.66 \pm 1.33$ & $75.02 \pm 11.25$ \\
\hline November & $22.42 \pm 1.45$ & $73.77 \pm 13.12$ \\
\hline December & $21.96 \pm 0.66$ & $84.38 \pm 5.49$ \\
\hline
\end{tabular}

"Values are means \pm standard deviation.

\subsection{Color Measurement}

Color was determined in triplicate on whole grains using a HunterLab Colorimeter (ColorQuest XE, Reston, Virginia). Prior to analysis, the instrument was calibrated against a standard white reference tile $\left(\mathrm{L}^{*}=97.55, \mathrm{a}^{*}=1.32, \mathrm{~b}^{*}=1.41\right)$. The color results were expressed in terms of Cielab scale parameters $L^{*}, a^{*}$ and $b^{*}$ representing lightness, red-green

and yellow-blue, respectively. Chroma $C^{*}\left(C^{*}=\sqrt{a^{2}+b^{2}}\right)$ and $\Delta E^{*}\left(\Delta E^{*}=\sqrt{\Delta L^{2}+\Delta a^{2}+\Delta b^{2}}\right)$,

representing total chromaticity and total color difference, respectively, between the standard and sample were calculated to compare color changes between samples.

\subsection{Cooking Time}

A Mattson Bean Cooker was used to record the mean cooking time as described previously (Wang \& Daun, 2005; Siqueira, Vianello, Fernandes, \& Bassinello, 2013). Prior to cooking, beans were soaked for $18 \mathrm{~h}$ in $100 \mathrm{~mL}$ distilled water at $25^{\circ} \mathrm{C}$ (Plhak, Caldwell, \& Stanley, 1989). The cooking proceeded by immersing the Mattson cooker in a beaker with boiling water $\left(98{ }^{\circ} \mathrm{C}\right)$ over a hotplate. Cooking time was defined as the $52 \%$ cooked point, indicated by plungers dropping and penetrating 13 of the individual beans, corresponding to the sensory preferred degree of cooking according to adapted methodology (Proctor \& Watts, 1987).

\subsection{Hardness Measurement}

A TA-XTplus texture analyser (Stable Micro Systems Ltd., Surrey, UK) was used for texture analysis of cooked beans. The return-to-start analysis method measured force under compression with a $2 \mathrm{~mm}$ cylindrical probe (P2), recording the peak maximum force. $\mathrm{P} 2$ is the probe commonly used for evaluating bean hardness because its small area affects the tegument and differentiates similar samples with soft cotyledons but hard tegument (Revilla \& Vivar-Quintana, 2008). Whole beans were axially compressed to $90 \%$ of its original height. Force-time curves were recorded at speed $5 \mathrm{~mm} / \mathrm{s}$ and the results corresponded to the average of about 30 measurements of individual cooked beans expressed in Newton $(\mathrm{N})$. The beans used in the test were soaked for $18 \mathrm{~h}$ and cooked in distilled water in a hot air oven for $2 \mathrm{~h}$ at $105{ }^{\circ} \mathrm{C}$ (Siqueira et al., 2013; Nasar-Abbas et al., 2008b).

\subsection{Lignin Assay}


Beans were manually dehulled with a scalpel, the seed coats discarded and the cotyledons ground (IKA® A11 basic analytical mill, São Paulo, Brazil) to obtain the flour used in determining lignin content. Prior to analysis, bean cotyledon flour $(500 \mathrm{mg})$ was washed with $10 \mathrm{~mL}$ of methanol $(1 \%$ concentrated $\mathrm{HCl})$, followed by two washes with distilled water $(5 \mathrm{~mL})$ to remove the phenolic compounds. Lignin of the phenolic-free material was measured by the thioglycolic acid method (Bruce \& West, 1988). The acid reacts with lignin in the presence of dilute $\mathrm{HCl}$ forming the lignin thioglicolate, which is resuspended in $\mathrm{NaOH}(0.5 \mathrm{M})$. The absorbance of the solution was monitored at $280 \mathrm{~nm}$ with a spectrophotometer (BEL Photonics SF200DM UV-Vis, Osasco, SP, Brazil) using lignin (Sigma-Aldrich, São Paulo, Brazil; 0 - 0.6 $\mathrm{mg} \mathrm{mL}-1)$ as standard and the values were expressed in $\mathrm{mg}$ lignin (100 g)-1 cotyledon flour.

\subsection{Statistical Analysis}

All tests were conducted according to a completely randomized design considering each genotype of carioca bean separately. The experiments were performed at least in three replicates. The main effects of genotypes and treatment and their interaction were analyzed independently and considered as fixed effects. Analysis of variance by the general linear models (GLM) procedure, means comparison by Tukey's test, Pearson correlation, variance components and principal component analysis were performed according to Statistical Analysis System, SAS 9.1 for windows (SAS, 1990). Cluster analysis was performed using SYSTAT 12 version 12.02 for windows (SYSTAT 12, 2007) using hierarchical clustering with Complete (linkage-farthest neighbor) and Mahalanobis (distance).

\section{Results and Discussion}

Beans were stored without any control of the environmental conditions. The temperature was almost constant $\left(22-25^{\circ} \mathrm{C}\right)$, whereas relative humidity (34-84\%) was highly variable during the storage period (Table 1). Temperature and relative humidity are the primary environmental factors that most affect bean cooking quality, since they promote humidity exchange between the grains and the environment, inducing a loss of integrity and quality (Arruda, Guidolin, Coimbra, \& Battilana, 2012; Morais, Valentini, Guidolin, Baldissera, \& Coimbra, 2010).

Analysis of variance for color indicators $\left(\mathrm{L}^{*}, \mathrm{a}^{*}, \mathrm{~b}^{*}, \mathrm{C}^{*}\right.$ and $\left.\Delta \mathrm{E}\right)$ and hardness of bean genotypes stored for five months (Table 2) showed that the main effects, genotype $(\mathrm{G})$ and storage time $(\mathrm{T})$ and their interaction $(\mathrm{G} \times \mathrm{T})$ were highly significant. $\mathrm{L}^{*}$ values at the end of 5 months storage ranged from 45.9 to 51.3 for slow or delayed darkening, and lower (42 - 44.9) for the regular darkening cultivars. Similar distinction has been observed between $\mathrm{L}^{*}$ values of light-colored and dark progenies of carioca bean (Silva et al., 2008). The reduction in $\mathrm{L}^{*}$ values of Pérola (22\%) stored for 3 months under refrigeration $\left(0{ }^{\circ} \mathrm{C}, 50 \% \mathrm{RH}\right)$ (Oliveira, 2009) or under ambient condition for 9 months (Brackman, Neuwald, Ribeiro, \& Freitas, 2002) was almost twice $(11.6 \%)$ that observed under our ambient condition $\left(\approx 25^{\circ} \mathrm{C}, 35 \% \mathrm{RH}\right)$. Generally, overall mean $L^{*}$ values decreased, whereas $a^{*}$ and $b^{*}$ values increased linearly $(r \geq 0.97)$, with the reduction rate of $\mathrm{L}^{*}$ values (-1.29) equivalent to the combined rate of increase in $\mathrm{a}^{*}$ and $\mathrm{b}^{*}$ values $(0.81+0.47)$ during storage. Furthermore, the rate of darkening (reduction in $\mathrm{L}^{*}$ value) was lower for delayed darkening $(-0.44$ to -1.28$)$ than those of the regular darkening $(\geq-1.63)$ genotypes. The increase in the rate of a* values was also lower for delayed darkening $(\leq 0.83, \mathrm{r}$ 
$=\geq 0.91)$ than those of the regular darkening $(\geq 0.88, r=\geq 0.96)$ cultivars. This is in accordance with previous report (Silva et al., 2008) that storage time accentuates the difference between quick darkening and darkening-resistant carioca beans. However, distinct difference was not observed in the rate increase in $b^{*}$ values between the two groups of cultivars during storage.

Table 2. Analysis of variance for color and hardness of carioca beans.

\begin{tabular}{|l|c|c|c|c|c|c|c|}
\hline \multirow{2}{*}{ Source } & \multicolumn{7}{|c|}{ Mean squares $^{*}$} \\
\cline { 2 - 8 } & $\mathrm{DF}$ & $\mathrm{L}^{*}$ & $\mathrm{a}^{*}$ & $\mathrm{~b}^{*}$ & $\mathrm{C}^{*}$ & $\Delta \mathrm{E}$ & Hardness \\
\hline Genotype (G) & 5 & $\begin{array}{c}1411 \\
(44.58)\end{array}$ & $\begin{array}{c}232 \\
(31.08)\end{array}$ & $\begin{array}{c}114 \\
(30.69)\end{array}$ & $\begin{array}{c}86.53 \\
(12.68)\end{array}$ & $\begin{array}{c}1193 \\
(36.36)\end{array}$ & $\begin{array}{c}129 \\
(0.84)\end{array}$ \\
\hline Treatment (T) & 5 & 1079 & 423 & 141 & 380 & 1428 & 1776 \\
& & $(33.78)$ & $(57.66)$ & $(38.47)$ & $(63.32)$ & $(43.82)$ & $(61.10)$ \\
\hline G x T & 25 & 41.40 & 9.03 & 8.82 & 13.16 & 43.78 & 106 \\
& & $(7.62)$ & $(7.43)$ & $(14.85)$ & $(13.29)$ & $(7.92)$ & $(22.77)$ \\
\hline Error & 1044 & 2.39 & 0.15 & 0.31 & 0.34 & 2.09 & 2.32 \\
& & $(14.02)$ & $(3.82)$ & $(15.99)$ & $(10.71)$ & $(11.90)$ & $(15.30)$ \\
\hline
\end{tabular}

*All mean squares are significant at 0.0001 probability levels. Values in parentheses are percent variance components.

The $\mathrm{a}^{*}$ value for Pérola increased $74 \%$ after 5 months storage that was higher than the $49 \%$ increase under conventional/ambient or minimal $(3 \%)$ increase under cold storage $\left(0{ }^{\circ} \mathrm{C}\right)$ reported previously (Brackman et al., 2002) for 9 months. Similarly, the increase in $b^{*}$ value for Pérola $(14.4 \%)$ after 5 months storage in our study was over twice $(2.8 \mathrm{x})$ that reported earlier (Brackman et al., 2002) (-5.8\%) under conventional/ambient or a similar reduction $(5.2 \%)$ under cold $\left(0{ }^{\circ} \mathrm{C}\right)$ storage.

The five bean color indicators were dependent primarily on genotype and storage time (Table 2 ). Genotype, storage time and their interaction contributed similarly to variation in $L^{*}$ and $\Delta \mathrm{E}$ values, whereas variation due to $\mathrm{G} x \mathrm{~T}$ interaction was similar only for $\mathrm{L}^{*}$, $\mathrm{a}^{*}$ and $\Delta \mathrm{E}$ values. Furthermore, from the percent variance components, genotype and storage time accounted for 13-45 and 34-63\% of the total variation in color indicators, respectively. Storage time accounted for over $50 \%$ of the total variation for $\mathrm{a}^{*}$ and $\mathrm{C}^{*}$ values and hardness, whereas genotype accounted for $45 \%$ of the total variation in $\mathrm{L}^{*}$ values. The genotype $\mathrm{x}$ storage time interaction had significant effect only for $\mathrm{a}^{*}, \mathrm{~b}^{*}$, and $\mathrm{C}^{*}$ values and hardness since their variance components were larger than that of the experimental error. The variation in hardness was due predominantly to storage time and its large component (23\%) for the interaction with genotype suggests that each genotype responded differently to storage conditions. Initially, grains had L* color values varying from 51.8 (Pérola) to 54.8 (CNFC10467) satisfactory for beans with high market value (Ribeiro, Storck, \& Poersch, 2008). Storage time modified color of all genotypes (Figure 1), becoming darker at the end of the storage time according to their greater or lesser susceptibility to the darkening phenomenon. 


\section{MInstitute Macrothink $_{\text {Int }}$}

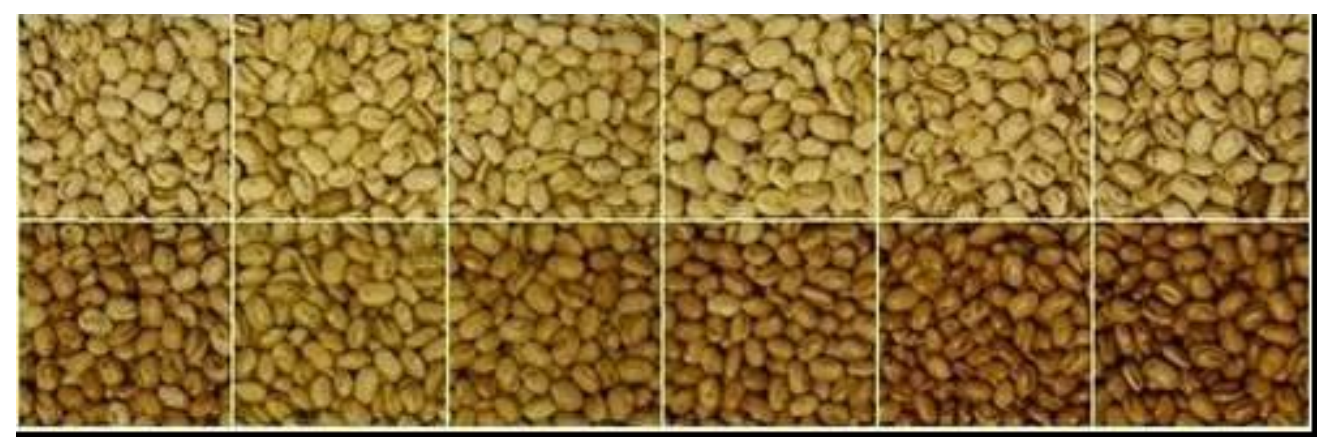

Figure 1. Bean genotypes freshly harvested (top row) and after five months storage (bottom row) under ambient conditions (from left to right: BRS Requinte, BRSMG Madrepérola, CNFC10467, BRS Estilo, BRS Pontal and Pérola).

All genotypes darkened after five months storage similar to those reported in pinto beans (Pirhayati, Soltanizadeh, \& Kadivar, 2011). However, the degree of darkening was different for each genotype (Figure 2-A), enabling identification of genotypes stable (CNFC1067 and Madrepérola) or susceptible (Pontal and Pérola) to the darkening process. Such differences can be explained by analyzing the chromaticity $\mathrm{a}^{*}$ and $\mathrm{b}^{*}$ data. Chromaticity $\mathrm{a}^{*}$, representing green to red color, increased in all genotypes throughout the shelf life (Figure 2-B). In terms of $\mathrm{a}^{*}$ value, all genotypes showed greater than $55 \%$ increase of the initial value, except Madrepérola, with an increase of only $17.8 \%$.

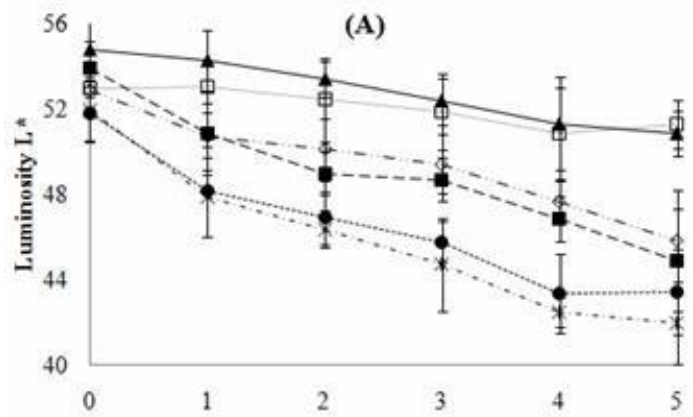

(C)

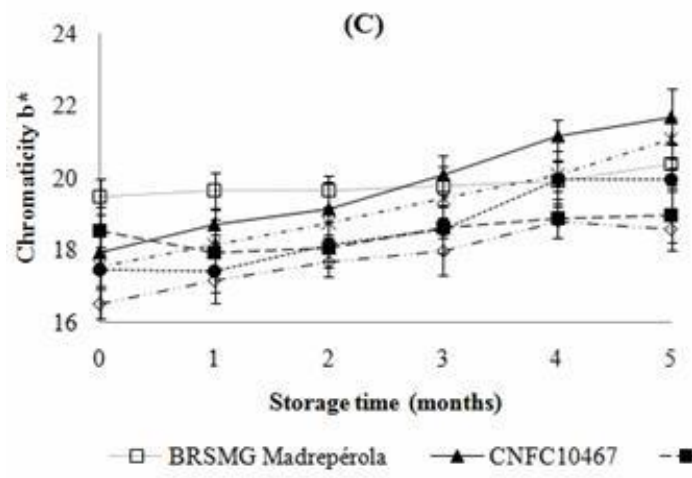

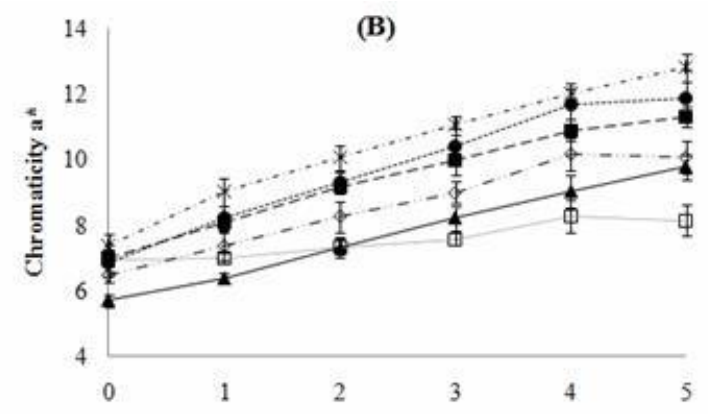

(D)

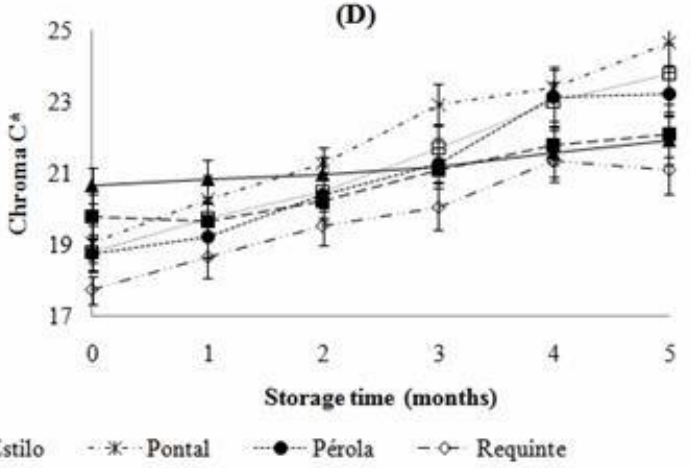

Figure 2. Luminosity (A), chromaticity a* (B), chromaticity b* (C) and chroma (D) of different carioca genotypes during storage at ambient condition.

The current market assessment of bean color is carried out visually among buyers based on the clarity of the grain, with a score of 10 given to lighter beans (Regras Especiais para Comercialização do Feijão, 2013). Luminosity determination has also been recommended and 
used in breeding programs to evaluate bean color stability of grain tegument (Ribeiro et al., 2008). However, this study shows that, in absolute terms, the $a^{*}$ values in the fifth month of storage were higher in genotypes with lower luminosity, indicating that these two color parameters jointly contribute to visual characteristics of bean darkening, and not only the tegument luminosity. This confirms previous report (Nasar-Abbas et al., 2009), that during bean darkening process the original reddish-brown color of grains change, followed by the loss of lightness.

The chromaticity $b^{*}$, ranging from yellow to blue, also increased in all genotypes during the shelf life (Figure 2-C), although the variation was lower than in luminosity and chromaticity a*. Genotypes CNFC10467 and Pontal showed the greatest increases ( 21\%) in b* chromaticity.

Chroma values (Figure 2-D) indicating the color saturation (Bal, Satya, \& Naik, 2011) were higher for Pontal $(19.0$ - 24.7). This result was expected, since this is a dark genotype. Nevertheless, the biggest changes in $\mathrm{C}^{*}$ are observed for Pontal and Madrepérola, with values increasing to 29.5 and 26.5, respectively. Substantial color changes occurred during storage for all seed samples: Madrepérola (2.2), CNFC10467 (6.8), Requinte (8.1), Estilo (10), Pérola (10.1), and Pontal (11.9).

Lower resistance to cooking has been a decisive factor, together with high clarity of grain tegument, in the acceptance of new cultivars. Cooking time is one of the required parameters for new cultivar registration in Brazil, and the Mattson Bean Cooker is recommended for its measurement (Ministério da Agricultura, Pecuária e Abastecimento [MAPA], 2013). Analysis of variance showed that cooking time was dependent on genotype, storage time (conditions), and their interaction (Table 2). Genotype, storage time and their interaction accounted for 19, 29 , and $52 \%$ of the total variation in cooking time, respectively. The high variance of the genotype and storage time interaction indicates that genotypes responded differently to each storage treatment, resulting in large fluctuations in cooking time within storage periods. The low genotype contribution to variation in cooking time compared to storage conditions is similar to those reported for beans subjected to five different storage periods and six different storage conditions (Arruda et al., 2012).

The cooking time of freshly harvested (T0) Pérola (20.8 min) was similar to those reported earlier (20.6 min) (Ribeiro et al., 2008). However, the increase in cooking time after 3 months storage was minimal (3.6\%) compared to the $26 \%$ increase observed in our study. This difference reflects the effects of various storage conditions on cooking time of this particular genotype. Cooking time of all genotypes increased with storage, except Requinte that showed reduced cooking time up to 4 months storage, followed by a sudden $(36 \%)$ increase after 5 months storage. The decrease $(17 \%)$ in cooking time after two months storage of Requinte was similar to the decrease $(18 \%)$ reported for beans under cold storage $\left(5{ }^{\circ} \mathrm{C}\right)$ for 35,42 and 53 days (Jacinto-Hernández et al., 2013). This reversible hardening has been associated with the pectin-phytate mechanism (Dell Valle \& Stanley, 1995). Minimal reduction (-3\%) in cooking time of Pérola stored for 3 months has also been reported (Ribeiro et al., 2008). CNFC 10467, Estilo and Pérola exhibited similar linear increase rate of cooking time (2.3, 2.8 and 3.5, respectively) during storage. A similar linear increase rate of cooking time $(3.5, \mathrm{r}=0.956)$ was 
reported for Pérola after 6 months storage under refrigeration $\left(0{ }^{\circ} \mathrm{C}, 50 \%\right.$ relative humidity) (Oliveira, 2009). Madrepérola and Pontal displayed a two stage increase in cooking time; the first linear increase in cooking time with storage up to 4 months (rates of 5.4 and $7.8 ; \mathrm{r}=0.93$ and 0.96 for Madrepérola and Pontal, respectively); the second stage was characterized by a sudden increase (57\% and $158 \%$ for Madrepérola and Pontal, respectively) in cooking time from the $4^{\text {th }}$ to the $5^{\text {th }}$ months storage. This accelerated (attenuated) increase in cooking time of Requinte, Madrepérola and Pontal coincides with the high relative humidity (> 87\%) encountered in the $5^{\text {th }}$ month storage. It also suggests that the observed hard-to-cook effect, particularly at high relative humidity $(\approx 70 \%)$ during storage, was not associated with (grain darkening characteristics) the genotypic distinction between delayed and regular darkening characteristics. Only cultivar Pontal had a 6-fold increase in cooking time for the 5 month stored sample relative to freshly harvested seed. A 4.5 fold increase in cooking time of carioca bean stored in an air-conditioned room $\left(23 \pm 3{ }^{\circ} \mathrm{C}, 65 \pm 5 \%\right.$ relative humidity) in fiber bags for 12 months has been reported previously (Steel, Sgarbieri, \& Jackix, 1995).

Considering the cooking time after harvest, it is possible to divide the genotypes into three groups: Madrepérola, Estilo and Pérola showed medium susceptibility to cooking (18, 19 and 20 min, respectively); CNFC10467 and Pontal showed normal resistance to cooking (22 min) and Requinte showed medium resistance (30 min) to cooking, according to the classification presented earlier (Ramos Júnior, Lemos, \& Silva, 2005). Cooking time increased during storage depending on genotypes (Table 3). In the second month of storage, CNFC10467 and Pontal distinguished themselves as the most resistant to cooking and therefore, more susceptible to the hardening (HTC) phenomenon. In contrast, Madrepérola and Estilo remained as genotypes with lower cooking resistance throughout the storage time.

Table 3. Cooking time (min) of bean genotypes during storage* .

\begin{tabular}{|l|l|c|c|c|c|c|}
\hline \multicolumn{7}{|c|}{ Storage time (months) } \\
\hline Genotypes & \multicolumn{1}{c|}{0} & \multicolumn{1}{c|}{1} & \multicolumn{1}{c|}{2} & \multicolumn{1}{c|}{3} & 4 & 5 \\
\hline Estilo & $19.5 \mathrm{bc}$ & $21.8 \mathrm{~b}$ & $22.6 \mathrm{c}$ & $26.6 \mathrm{c}$ & $28.8 \mathrm{~d}$ & $33.9 \mathrm{~d}$ \\
\hline Pontal & $22.8 \mathrm{~b}$ & $26.0 \mathrm{a}$ & $39.1 \mathrm{a}$ & $41.9 \mathrm{a}$ & $53.7 \mathrm{a}$ & $138.7 \mathrm{a}$ \\
\hline Requinte & $30.7 \mathrm{a}$ & $22.9 \mathrm{~b}$ & $25.5 \mathrm{c}$ & $25.9 \mathrm{c}$ & $28.7 \mathrm{~d}$ & $38.9 \mathrm{c}$ \\
\hline CNFC10467 & $21.7 \mathrm{bc}$ & $22.5 \mathrm{~b}$ & $33.9 \mathrm{~b}$ & $35.9 \mathrm{~b}$ & $42.0 \mathrm{~b}$ & $66.1 \mathrm{~b}$ \\
\hline Madrepérola & $18.7 \mathrm{c}$ & $17.9 \mathrm{c}$ & $23.3 \mathrm{c}$ & $26.4 \mathrm{c}$ & $24.7 \mathrm{e}$ & $29.9 \mathrm{e}$ \\
\hline Pérola & $20.8 \mathrm{bc}$ & $22.9 \mathrm{~b}$ & $24.9 \mathrm{c}$ & $26.1 \mathrm{c}$ & $35.6 \mathrm{c}$ & $37.5 \mathrm{c}$ \\
\hline Overall mean & $22.4 \mathrm{E}$ & $22.3 \mathrm{E}$ & $28.2 \mathrm{D}$ & $30.5 \mathrm{C}$ & $35.6 \mathrm{~B}$ & $57.5 \mathrm{~A}$ \\
\hline $\mathrm{CV}^{* *}$ & 9.2 & 6.5 & 6.3 & 4.1 & 4.9 & 2.3 \\
\hline
\end{tabular}

"Means in a column followed by the same letter are not significantly different at the $5 \%$ level. ${ }^{* *}$ Coefficient of variation.

Grain hardness measured instrumentally is another parameter used in determining the technological quality of beans. During the cooking process the pectic substances decompose, the connection between the cells weakens and the hardness decreases (Zamindar, Baghekhandan, Nasirpour, \& Sheikhzeinoddlin, 2013). The hardness (Table 4) of cooked freshly harvested grain was lower in Requinte and Pérola (1.8 and $4.9 \mathrm{~N}$, respectively) compared with other genotypes ( 9.9 to $10.5 \mathrm{~N}$ ), probably due to genetic characteristics of these grains or the interaction of genetic and environmental factors (Corte, Moda-Cirino, Schoz, \& 
Destro, 2003; Paredez-López, Reyes-Moreno, Montes-Rivera, \& Carabez-Trejo, 1989). A similar hardness (4.18) was reported for Pérola based on sensory evaluation (Oliveira, Ribeiro, Joste, Colpo, Poersch, 2013). All genotypes, except Pérola and Requinte, showed increased hardness (35-52\%) after 2 months storage relative to freshly harvested grains. Similar increase $(55 \%)$ in hardness was recently reported (Coelho et al., 2013) for carioca bean (Iapar 81) after 2 months cold storage $\left(5{ }^{\circ} \mathrm{C}\right)$ that was highly elevated $(128 \%)$ under accelerated aging $\left(40{ }^{\circ} \mathrm{C}\right.$, $76 \% \mathrm{RH})$.

The lignin content in freshly harvested grains ranged from 0.33 to $0.42 \mathrm{mg}(100 \mathrm{~g})-1$ and after one month of storage it varied from 0.28 to $0.44 \mathrm{mg}(100 \mathrm{~g})-1$ (Figure 3$)$. Although the grain hardness increased significantly after one month storage, the lignin content did not follow the same pattern. Lignin content increased only in CNFC10467 and remained unchanged or reduced in other genotypes. This suggests that the hardening observed in genotypes cannot always be attributed to the lignification process as proposed by other investigators (Del Valle \& Stanley, 1995; Nasar-Abbas et al., 2008b). Other metabolic pathways are probably involved in this process, contributing significantly to the HTC phenomenon.

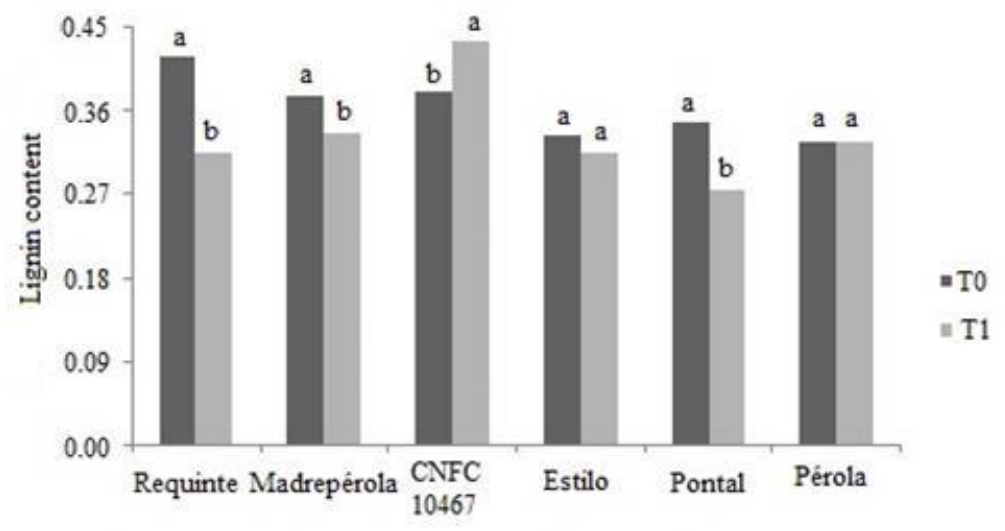

Figure 3. Lignin content $\left[\mathrm{mg}(100 \mathrm{~g})^{-1}\right]$ in the cotyledons of freshly harvested (T0) and one month stored (T1) carioca beans under ambient conditions.

Bars with different letters between times T0 and T1 for the same genotype are significantly different $(\mathrm{p}<0.05)$.

Increase in cooking time was significantly correlated with storage time $(\mathrm{r}=0.89$ to $0.98, \mathrm{P}<$ $0.05)$ and color parameters $L^{*}(r=-0.60$ to -0.96$), a^{*}(r=0.59$ to 0.96$)$ and $b^{*}(r=0.66$ to 0.94$)$ in most genotypes. CNFC10467 and Pontal displayed higher cooking resistance than other genotypes $(>1 \mathrm{~h})$, despite their contrasting darkening process. Similarly, the hardness of the cooked beans had no or low correlation $(\mathrm{r}=<-0.44)$ with grain luminosity, chromaticity $\mathrm{a}^{*}(\mathrm{r}=$ $<0.56)$ and $b^{*}(r=<0.50)$. So, it can be inferred that the color of the tegument of carioca beans is not an appropriate or fully reliable parameter for predicting the cooking resistance or hardness of these grains, as has been used by merchants and consumers. The lignin content showed poor correlation with the cooking time (except for genotype Pérola, which showed positive correlation; $r=0.86)$ and the hardness of the cooked grains $(r=<0.45)$, which confirms again that this component is not associated with greater resistance to cooking and 
hardness observed in genotypes throughout their shelf life.

Table 4. Hardness $(\mathrm{N})$ of bean genotypes during storage ${ }^{*}$.

\begin{tabular}{|l|c|c|c|c|c|c|}
\hline \multicolumn{7}{|c|}{ Storage time (months) } \\
\hline \multicolumn{1}{|c|}{ Genotypes } & 0 & 1 & 2 & 3 & 4 & 5 \\
\hline Estilo & $10.49 \mathrm{c}$ & $16.27 \mathrm{a}$ & $15.48 \mathrm{ab}$ & $14.62 \mathrm{~b}$ & $14.75 \mathrm{~b}$ & $14.92 \mathrm{~b}$ \\
\hline Pontal & $10.11 \mathrm{c}$ & $13.75 \mathrm{~b}$ & $13.66 \mathrm{~b}$ & $13.84 \mathrm{~b}$ & $14.59 \mathrm{a}$ & $13.19 \mathrm{~b}$ \\
\hline Requinte & $1.77 \mathrm{c}$ & $15.20 \mathrm{c}$ & $15.36 \mathrm{c}$ & $16.61 \mathrm{a}$ & $16.72 \mathrm{a}$ & $15.41 \mathrm{~b}$ \\
\hline CNFC10467 & $9.97 \mathrm{c}$ & $16.37 \mathrm{a}$ & $15.16 \mathrm{~b}$ & $15.18 \mathrm{~b}$ & $15.83 \mathrm{ab}$ & $16.28 \mathrm{a}$ \\
\hline Madrepérola & $10.36 \mathrm{~d}$ & $17.66 \mathrm{a}$ & $15.72 \mathrm{~b}$ & $14.45 \mathrm{c}$ & $15.57 \mathrm{~b}$ & $16.41 \mathrm{~b}$ \\
\hline Pérola & $5.24 \mathrm{c}$ & $17.46 \mathrm{a}$ & $17.75 \mathrm{a}$ & $17.17 \mathrm{a}$ & $17.91 \mathrm{a}$ & $16.18 \mathrm{~b}$ \\
\hline Overall mean & $7.99 \mathrm{C}$ & $16.12 \mathrm{~A}$ & $15.52 \mathrm{~B}$ & $15.31 \mathrm{~B}$ & $15.89 \mathrm{~A}$ & $15.40 \mathrm{~B}$ \\
\hline CV & 19.68 & 9.74 & 11.30 & 10.84 & 6.92 & 9.10 \\
\hline
\end{tabular}

"Means in a column followed by the same letter are not significantly different at the $5 \%$ level. ${ }^{* * *}$ Coefficient of variation.

Principal component analysis (PCA) was performed on the eight constituents (excluding moisture) analyzed in this study to explore their underlying complex interrelationships (Figure 4). The PCA analysis generated two factors with eigenvalue exceeding 1.0 (Kaiser's rule) that accounted for $76 \%$ of the total variance. The first component (F1) accounting for $55 \%$ of total variance had large, approximately equal positive loadings for color indicators (attributes); $\mathrm{a}^{*}$ values $(0.45)$, chromaticity $C^{*}(0.43), \Delta \mathrm{E}^{*}$ values $(0.41)$ and negative loading for lightness $\mathrm{L}^{*}$ values $(-0.41)$. The second component $(\mathrm{F} 2,21 \%)$ was primarily influenced by a positive loading for $\mathrm{b}^{*}$ values $(0.54)$ and lignin $(0.64)$. The third component (F3) with eigenvalue equal to 1 , accounted for $12 \%$ of total variance with large negative $(-0.74)$ and positive $(0.59)$ contributions for hardness and cooking time, respectively.

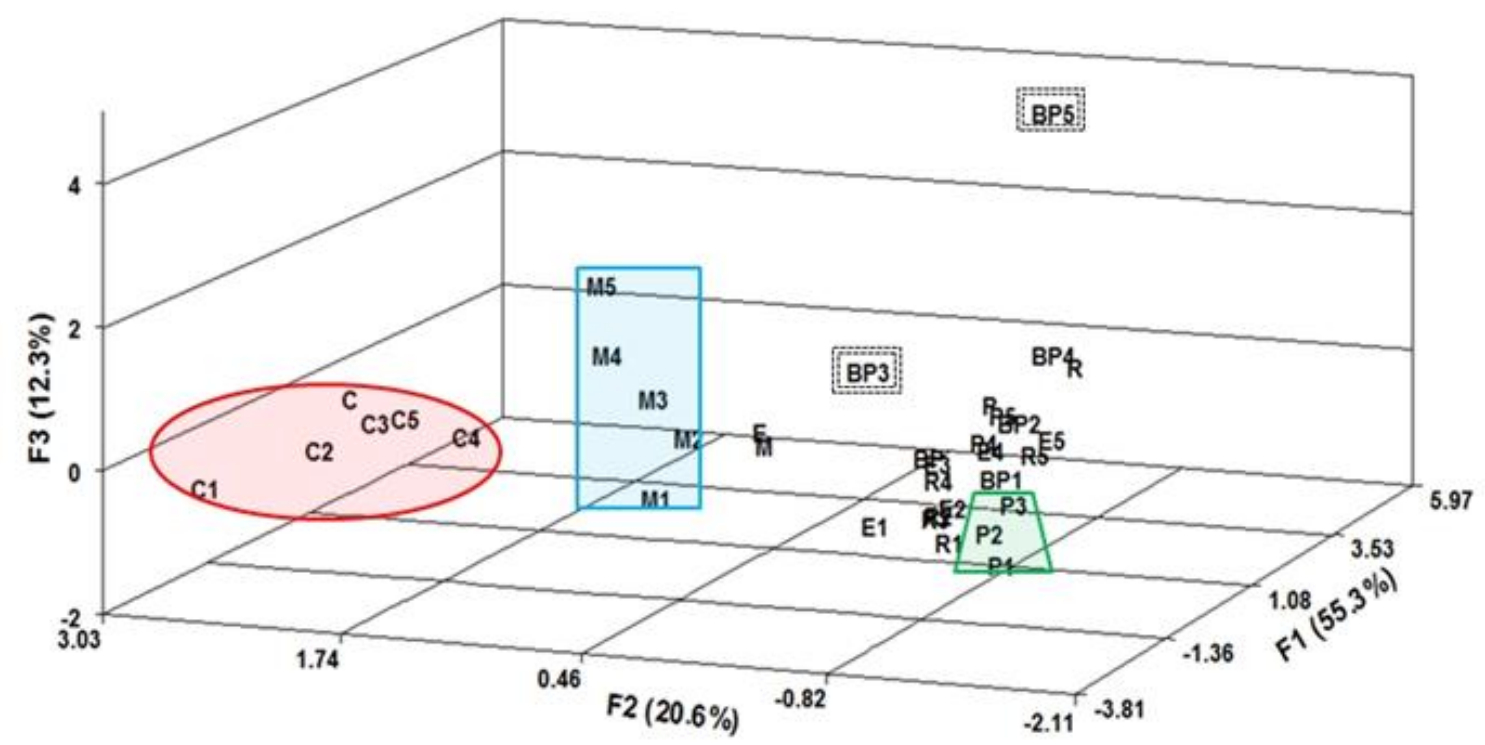

Figure 4. Classification of carioca beans genotypes grouped according to principal components 
1,2 and 3.

Genotypes BRS Estilo, BRS Requinte, CNFC10467, BRSMG Madrepérola, BRS Pontal and Pérola are denoted, respectively, E, R, C, M, BP and P. Numbers following the genotype names represents the storage time.

The three dimensional plot (Figure 4) illustrates the distribution of the genotypes based on the first three principal components accounting for $88 \%$ of the total variance. The plot revealed strong differences in cooking time, hardness and color indicators in bean genotypes. Thus, the genotype with the longest cooking time Pontal at five month storage (BP5) with highest positive loadings on F1, and the lowest lightness $\mathrm{L}^{*}$ values (BP5 and BP3) grouped based on their smallest /negligible contribution to F2 (predominantly dependent on lignin and $\mathrm{b}^{*}$ values). The PCA plot grouped the delayed darkening genotypes CNFC10467 (C, C1, C2, C3 and C5) and Madrepérola during storage (M1, M2, M3, M4, M5) due to their positive high contributions to F2, separating them from the rest of the samples with negative scores for F2. Samples P1, P2 and P3 clustered together based on their high hardness value (> 17), primary factor for F3. The dendogram (Figure 5) obtained from cluster analysis based on the same variables displayed three major discrete clusters with BP5 and BP3 at extreme ends of the cluster depicting the extreme prolonged cooking time (BP5-139 min) and one of the smallest $\triangle \mathrm{E}$ values (BP3-42.5). The genotype CNFC10467 (C) segregated as a sub-cluster from the stored beans largely based on short/fast cooking time $(<30 \mathrm{~min}$; and $<19$ min, particularly for C1 and C), high similar $b^{*}(>19), L^{*}(50-53)$ and lignin $(<0.27)$ values. M5, M4 and M3 comprised a sub-cluster based on high cooking time (> $35 \mathrm{~min}$ ) and $b^{*}$ value $(>20)$, whereas samples with low $\mathrm{a}^{*}$ value $(<10)$ formed the sub-cluster consisting of $\mathrm{P}, \mathrm{R}, \mathrm{M}, \mathrm{M} 1, \mathrm{R} 1, \mathrm{P} 1$ and P2. Samples P, R and M also had low hardness values $(<10)$. Similarly, BP4, P5 and P4 clustered with the highest $\mathrm{a}^{*}(>11.5), \mathrm{C}^{*}(\sim 23)$ and $\Delta \mathrm{E}(>54)$ values and lowest $\mathrm{L}^{*}$ value $(<$ 44) and high cooking time (> 35). E5, E4, E3 and R4 formed a sub-cluster with similar $\mathrm{b}^{*}$ value (18.6-18.9) and hardness (14.6-15). The largest cluster consisted of 15 samples comprising mostly the regular darkening genotypes Estilo (E-E5), Pontal (BP, BP1 and BP2), Pérola (P3), as well as the delayed darkening genotype Requinte (R2, R3, R4 and R5). Two sub-clusters, (M5, M4 and M3) and (P1 and P2) as well as the CNFC10467 (C1, C, C2, C3, $\mathrm{C} 4$, C5) showed similar grouping in both the principal component and cluster analyses thereby confirming and validating the results. 


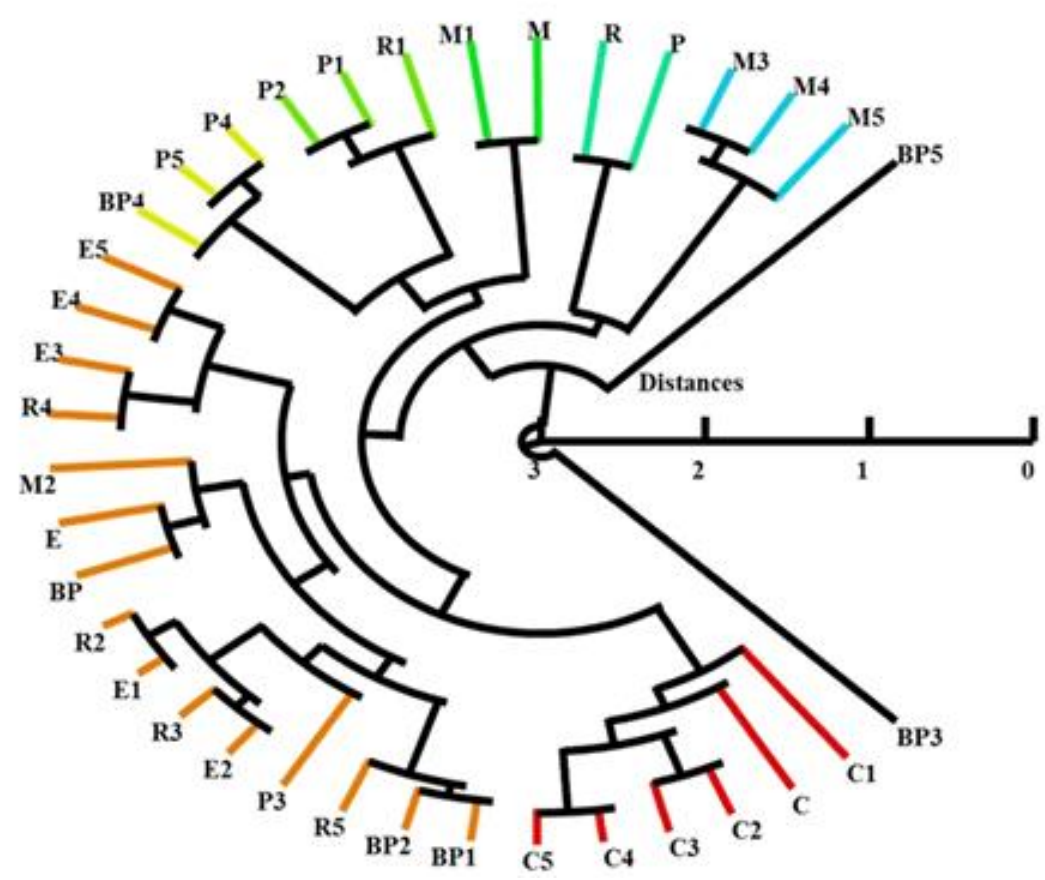

Figure 5. Dendogram of cluster analysis (Ward Euclidean) performed on 8 constituents (CT, L*, $a^{*}, b^{*}, H D, C^{*}, \Delta E$, lignin) of carioca bean genotypes BRS Estilo (E), BRS Requinte (R), CNFC10467 (C), BRSMG Madrepérola (M), BRS Pontal (BP) and Pérola (P).

Numbers following the genotype names represents the storage time.

\section{Conclusions}

There is a trend of darkening and hardening of carioca beans along the shelf life, but these events occur at different intensities for each genotype and are not always correlated. The luminosity parameter alone is not a suitable marker for identification of genotypes stable to changes in color, and the chromaticity $\mathrm{a}^{*}$ and $\mathrm{b}^{*}$ are equally important in the understanding of the darkening shown by the genotypes in postharvest. The color of the seed coat is not an appropriate parameter for predicting the hardness or resistance for cooking acquired by carioca beans throughout shelf life. The hardness observed in genotypes during storage cannot be attributed solely to the process of tissue lignification, but is probably related to other metabolic pathways. Among the genotype analyzed, BRSMG Madrepérola is not affected by storage (resistant to storage conditions), whereas BRS Pontal is the opposite and highly susceptible to storage conditions both due to extended cooking time and darkening (low $\mathrm{L}^{*}$ values).

\section{Acknowledgement}

The authors would like to acknowledge the Coordenação de Aperfeiçoamento de Pessoal de Nível Superior (CAPES) and Embrapa Rice and Beans for the scholarship and financial support. We are also thankful to the breeder Dr. Helton Santos Pereira and his assistant Vicente Henrique Afonso Tavares from Embrapa Rice and Beans for helping us with the genotypes cultivation. 


\section{References}

Araújo, A. de L. C., Ramalho, M. A. P., \& Abreu, A. de F. B. (2012). Estimates of genetic parameters of late seed-coat darkening of carioca type dry beans. Ciência e Agrotecnologia, 36(2), 156-162. http://dx.doi.org/10.1590/S1413-70542012000200003

Arruda, B., Guidolin, A. F., Coimbra, J. L. M., \& Battilana, J. (2012). Environmental is crucial to the cooking time of beans. Ciência e Tecnologia de Alimentos, 32(3), 573-578. http://dx.doi.org/10.1590/S0101-20612012005000078

Bal, L. M., Kar, A., Satya, S., \& Naik, S. N. (2011) Kinetics of colour change of bamboo shoot slices during microwave drying. International Journal of Food Science and Technology, 46, 827-833. http://dx.doi.org/10.1111/j.1365-2621.02553.x

Beninger, C. W., Gu, L., Prior, R. L., Junk, D. C., Vandenberg, A., \& Bett, K. E. (2005) Changes in Polyphenols of the Seed Coat during the After-Darkening Process in Pinto Beans (Phaseolus vulgaris L.). Journal of Agricultural and Food Chemistry, 53, 7777-7782.

Berrios, J. J., Swanson, B. G., \& Cheongh, A. (1998). Structural characteristics of stored black beans (Phaseolus vulgaris L.). Scanning, 20, 410-417. http://dx.doi.org/10.1002/sca.1998.4950200507

Brackman, A., Neuwald, D. A., Ribeiro, N. D., \& Freitas, S. T. (2002). Conservação de três genótipos de feijão (Phaseolus vulgaris L.) do grupo carioca em armazenamento refrigerado e em atmosfera controlada. Ciência Rural, 32(6), 911-915. http://dx.doi.org/10.1590/S0103-84782002000600001

Bruce, R. J., \& West, C. A. (1988). Elicitation of lignin biosynthesis and isoperoxidase activity by pectic fragments in suspension cultures of castor bean. Plant Physiology, 91, 889-897. http://dx.doi.org/10.1104/pp.91.3.889

Cardador-Martínez, A., Loarca-Piña, G., \& Oomah, B. D. (2002). Antioxidant activity in common beans (Phaseolus vulgaris L.). Journal of Agricultural and Food Chemistry, 50, 6975-6980. http://dx.doi.org/10.1021/jf02296n

Coelho, S. R. M., Prudêncio, S. H., Christ, D., Sampaio, S. C., \& Schoeninger, V. (2013). Physico-chemical characterization of common beans under natural and accelerated storage conditions. Ciencia Investigación Agraria, 40(3), 629-636. http://dx.doi.org/10.4067/S0718-16202013000300015

Coelho, S. R. M., Prudêncio, S. H., Nóbrega, L. H. P., \& Leite, C.F. R. (2009). Alterações no tempo de cozimento e textura dos grãos de feijão comum durante o armazenamento. Ciência e Agrotecnologia, 33, 539-544. http://dx.doi.org/10.1590/S1413-70542009000200028

Corte, A. D., Moda-Cirino, V., Schoz, M. B. S., \& Destro, D. (2003). Environment effect on grain quality in early common bean cultivars and lines. Crop Breed Applied Biotechnology, 3,193-202. http://dx.doi.org/10.12702/1984-7033.v03n03a03

Del Valle, J. M., \& Stanley, D. W. (1995). Reversible and irreversible components of bean 
hardening. Food Research International, 28(5), 455-463. http://dx.doi.org/10.1016/0963-9969(96)81392-5

Garcia, E., Filisetti, T. M. C. C., Udaeta, J. E. M., \& Lajolo, F. M. (1998). Hard-to-cook beans (Phaseolus vulgaris): Involvement of phenolic compounds and pectates. Journal of Agricultural and Food Chemistry, 46, 2110-2116. http://dx.doi.org/10.1021/jf970848f

Jacinto-Hernández, C., Garza-García, D., Garza-García, R., \& Bernal-Lugo, I. (2013). Reversibility of seed hardness in dry bean genotypes. Annual Report of the Bean Improvement Cooperative, 56, 19-20.

Lemos, L. B., Oliveira, R. S., Palomino, E. C., \& Silva, T. R. B. (2004). Características agronômicas e tecnológicas de genótipos de feijão do grupo comercial Carioca. Pesquisa Agropecuária Brasileira, 39, 319-326. http://dx.doi.org/10.1590/S0100-204X2004000400004

Leterme, P., \& Muñoz, C. (2002). Factors influencing pulse consumption in Latin America. British Journal of Nutrition, 88, S251-254. http://dx.doi.org/10.1079/BJN/2002714

Ministério da Agricultura, Pecuária e Abastecimento. (2013). Requisitos mínimos para a determinação do Valor de Cultivo e Uso de feijão (Phaseolus vulgaris) para a inscrição no Registro Nacional de Cultivares-RCN. Brasilia: MAPA, 2006. Anexo IV. Retrieved September 25, 2013, from http://www.agricultura.gov.br

Morais, P. P. P., Valentini, G., Guidolin, A. F., Baldissera, J. N. C., \& Coimbra, J. L. M. (2010). Influência do período e das condições de armazenamento de feijão no tempo de cocção. Revista Ciência Agronômica, 41, 593-598. http://dx.doi.org/10.1590/S1806-66902010000400011

Nasar-Abbas, S. M., Plummer, J. A., Siddique, K. H. M., White, P., Harris, D., \& Dods, K. (2008). Nitrogen retards and oxygen accelerates colour darkening in faba bean (Vicia faba L.) during storage. Postharvest Biology and Technology, 47, 113-118. http://dx.doi.org/10.1016/j.postharvbio.2007.06.007

Nasar-Abbas, S. M., Plummer, J. A., Siddique, K. H. M., White, P., Harris, D., \& Dods, K. (2008). Cooking quality of faba bean after storage at high temperature and the role of lignins and other phenolics in bean hardening. LWT - Food Science and Technology, 41, 1260-1267. http://dx.doi.org/10.1016/j.lwt.2007.07.017

Nasar-Abbas, S. M., Siddique, K. H. M., Plummer, J. A., White, P. F., Harris, D., Dods, K., \& D'antuono, M. (2009). Faba bean (Vicia faba L.) seeds darken rapidly and phenolic content falls when stored at higher temperature, moisture and light intensity. LWT-Food Science and Technology, 42, 1703-1711. http://dx.doi.org/10.1016/j.lwt.2009.05.013

Oliveira, V. R. (2009). Analise fisico-quimica, microbiologica e sensorial de cultivares de feijão (Doctoral dissertation, Universidade Federal de Santa Maria, Santa Maria, Brazil). Retrieved from http://w3.ufsm.br/biblioteca

Oliveira, V. R., Ribeiro, N. D., Joste, E., Colpo, E., \& Poersch, N. L. (2013). Perfil sensorial de cultivares de feijão sob diferentes tempos de cozimento. Brazilian Journal of Food and Nutrition, 24(2), 145-152. 
Oomah, B. D., Corbe, A., \& Balasubramanian, P. (2010). Antioxidant and anti-inflammatory activities of bean (Phaseolus vulgaris L.) hulls. Journal of Agricultural and Food Chemistry, 58, 8225-8230. http://dx.doi.org/10.1021/jf1011193

Paredez-Lópes, O., Reyes-Moreno, C., Montes-Rivera, R., \& Carabez-Trejo, A. (1989). Hard-to-cook phenomenon in common beans - influence of growing location and hardening procedures. International Journal of Food Science and Technology, 24, 535-542. http://dx.doi.org/10.1111/j.1365-2621.1989.tb00677.x

Pirhayati, M., Soltanizadeh, N., \& Kadivar, M. (2011). Chemical and microstructural evaluation of 'hard-to-cook' phenomenon in legumes (pinto bean and small-type lentil). International Journal of Food Science and Technology, 46, 1884-1890. http://dx.doi.org/10.1111/j.1365-2621.2011.02697.x

Plhak, L. C., Caldwell, K. B., \& Stanley, D. W. (1989). Comparison of methods used to characterize water imbibitions in hard-to-cook beans. Journal of Food Science, 54, 326-329. http://dx.doi.org/10.1111/j.1365-2621.1989.tb03073.x

Proctor, J. R., \& Watts, B. M. (1987). Development of a modified Mattson Bean Cooker procedure based on sensory panel cookability evaluation. Canadian Institute of Food Science and Technology Journal, 20, 9-14. http://dx.doi.org/10.1016/S0315-5463(87)70662-2

Ramos Júnior, E. U., Lemos, L. B., \& Silva, T. R. B. (2005). Componentes da produção, produtividade de grãos e características tecnológicas de cultivares de feijão. Bragantia, 64,75-82. http://dx.doi.org/10.1590/S0006-87052005000100008

Regras Especiais para Comercialização do Feijão. (2013). Retrieved from http://www.bbmnet.com.br/pages/portal/bbmnet/arquivos/documentos/Anexo-III-do-Regula mento-de-Comercializacao-de-Feijao.pdf

Revilla, I., \& Vivar-Quintana, A. M. (2008). Effect of canning process on texture of Faba beans $\begin{array}{lllll}\text { (Vicia faba). } & \text { Food 310-314. }\end{array}$ http://dx.doi.org/10.1016/j.foodchem.2007.02.046

Ribeiro, N. D., Rodrigues, J. A., Cargnelutti Filho, A., Poersch, N. L., Trentin, M., \& Rosa, S. S. (2007). Efeito de períodos de semeadura e das condições de armazenamento sobre a qualidade de grãos de feijão para o cozimento. Bragantia, 66, 157-163. http://dx.doi.org/10.1590/S0006-87052007000100019

Ribeiro, N. D., Storck, L., \& Poersch, N. L. (2008). Classificação de lotes comerciais de feijão por meio da claridade do tegumento dos grãos. Ciência Rural, 38, 2042-2045. http://dx.doi.org/10.1590/S0103-84782008000700039

SAS. (1990). SAS/STAT User's Guide, Version 6, 4th ed., SAS Institute, Inc., Cary, NC, 891-996.

Silva, F. C., Pereira, H. S., Melo, L. C., Melo, P. G. S., Wendland, A., Ferreira, B. H., \& Paiva, B. A. R. (2011). Selection of segregating populations with delayed darkening in carioca type common beans. Annual Report of the Bean Improvement Cooperative, 54, 42-43. 
Silva, G. S., Ramalho, M. A. P., Abreu, Â. D. F. B., \& Silva, F. B. (2008). Genetic control of early grain darkening of carioca common bean. Crop Breeding and Applied Biotechnology, 8, 299-304.

Siqueira, B. S., Teixeira, J. V., \& Bassinello, P. Z. (2012). Differences in stability of common bean genotypes to darkening and hardening process during storage. Annual Report of the Bean Improvement Cooperative, 55, 233-234.

Siqueira, B. S., Vianello, R. P., Fernandes, K. F., \& Bassinello, P. Z. (2013). Hardness of carioca beans (Phaseolus vulgaris L.) as affected by cooking methods. LWT-Food Science and Technology, 54, 13-17. http://dx.doi.org/10.1016/j.lwt.2013.05.019

Steel, C. J., Sgarbieri, V. C., \& Jackix, M. H. (1995). Use of extrusion technology to overcome undesirable properties of hard-to-cook dry beans (Phaseolus vulgaris L.). Journal of Agriculture and Food Chemistry, 43, 2487-2492. http://dx.doi.org/10.1021/jf00057a031

SYSTAT 12. (2007). STATISTICS I, Chapter 4, Cluster Analysis, SYSTAT Software Inc., San Jose, CA I65-I124.

Torga, P. P., Pereira, H. S., Melo, L. C., Bassinello, P. Z., Carvalho, H. W. L., Costa, A. F., ... Melo, P. G. S. (2011). Cooking time of common beans carioca type evaluated in different environments. Annual Report of the Bean Improvement Cooperative, 54, 40-41.

Wang, N., \& Daun, J. K. (2005). Determination of cooking times of pulses using an automated Mattson cooker apparatus. Journal of the Science of Food and Agriculture, 85, 1631-1635. http://dx.doi.org/10.1002/jsfa.2134

\section{Copyright Disclaimer}

Copyright for this article is retained by the author(s), with first publication rights granted to the journal.

This is an open-access article distributed under the terms and conditions of the Creative Commons Attribution license (http://creativecommons.org/licenses/by/3.0/). 